\title{
Peran "Cakruk Baca Bergerak" Dalam Pengembangan Literasi Anak Usia Dini
}

\author{
Sri Marwiyati \\ Institut Agama Islam Negeri (IAIN) Salatiga \\ Email:marwi.piaud@iainsalatiga.ac.id \\ M. Agung Hidayatulloh \\ Institut Agama Islam Negeri (IAIN) Salatiga \\ Email: agunghidayat@iainsalatiga.ac.id \\ ORCID: 0000-0001-8847-9308
}

Article received: 31 Agustus 2018, Review process: 31 Agustus 2018

Article published: 30 September 2018

\begin{abstract}
This paper describes the role of Cakruk Baca Bergerak (Cak Bager) in developing early childhood literacy in RA Miftahul Falah as well as its supporting and inhibiting factors. This qualitative study used observation, interview, and documentation for data collection techniques. Cak Bager contributes positively to children in RA Miftahul Falah. Children free to express themselves by learning to read, write, color, tell stories, and ask questions. Children become closer to books, play with books, even if they just go back and forth to see pictures and tell it to their friends. In addition, Cak Bager also provides activities such as coloring competitions, storytelling, and role playing. Variations in these activities can overcome child boredom so that the purposes of literacy development run well. Literacy development through Cak Bager in RA Miftahul Falah was supported by quite a large collection of books, book grants from the government to managers of Cak Bager, provision of time and place by schools, mentoring teachers and parents to children while in school, and the collaboration of Cak Bager managers with literacy activists. On the other hand, these efforts encountered obstacles in the forms of limited time for visits, lack of facilities and infrastructure for reading at home, and lack of reading culture at home.
\end{abstract}

Keywords: cakruk baca bergerak, literacy, early children

\section{Abstrak}

Tulisan ini mendeskripsikan tentang peran Cakruk Baca Bergerak (Cak Bager) dalam mengembangkan literasi anak usia dini di RA Miftahul Falah beserta faktor pendukung dan penghambatnya. Kajian kualitatif ini memanfaatkan teknik pengumpulan data berupa observasi, wawancara, dan dokumentasi. Hasilnya adalah Cak Bager berkontribusi positif kepada anak-anak di RA Miftahul Falah. Anak-anak menjadi lebih bebas berekspresi dengan belajar membaca, menulis, mewarnai, bercerita, dan bertanya. Anak mulai dekat dengan buku, bermain dengan buku, meski hanya sekadar membolak-balik untuk melihat gambar dan menceritakan hal itu kepada temannya. Di samping itu, Cak Bager juga menyediakan kegiatan seperti lomba mewarnai, bercerita, dan bermain peran. Variasi kegiatan itu dapat mengatasi kebosanan anak sehingga tujuan dari pengembangan literasi dapat berkembang baik. Pengembangan literasi melalui Cak Bager di RA Miftahul Falah didukung dengan cukup banyaknya koleksi buku untuk anak, hibah buku dari pemerintah kepada 
pengelola Cakruk Baca, penyediaan waktu dan tempat oleh sekolah, pendampingan guru dan orang tua kepada anak selama di sekolah, dan kerja sama pengelola Cak Bager dengan pegiat literasi. Di sisi lain, upaya tersebut menemui hambatan berupa keterbatasan waktu kunjungan, minimnya sarana dan prasarana untuk membaca di rumah, dan kurangnya budaya membaca di rumah.

Kata Kunci: cakruk baca bergerak, literasi, anak usia dini

\section{PENDAHULUAN}

Teknologi adalah sesuatu yang bermanfaat untuk mempermudah semua aspek kehidupan manusia. Teknologi telah berkembang pesat dan semakin canggih seperti halnya hadirnya gadget yang menawarkan berbagai macam kemudahan dalam mengakses informasi. Daya tarik berbagai teknologi saat ini mengakibatkan jarangnya interaksi siswa dengan bahan bacaan karena mereka terlalu asyik dengan berbagai alat multimedia yang bisa mengurangi intensitas membaca buku. Kebanyakan para siswa terlalu sibuk mengakses media internet dan alat-alat media komunikasi dan elektronik sehingga mereka malas untuk membaca dan melupakan belajar, sedangkan tugas utama para siswa adalah belajar. Tetapi pada kenyataannya para siswa lebih senang untuk bermain handphone daripada pergi ke perpustakaan untuk membaca buku.

Indonesia dalam hal membaca masih sangat rendah. Kegiatan membaca tidak menjadi prioritas di negeri ini. Membaca buku sangat sulit dilakukan dan dibiasakan oleh generasi muda. Membaca mungkin kegiatan yang mudah dilakukan, namun susah untuk dijadikan kebiasaan bahkan kewajiban. Bosan dan jenuh cepat menghampiri ketika mulai melakukan kegiatan membaca, sehingga generasi muda merasa bahwa membaca merupakan kegiatan yang membosankan. Saat ini gerakan literasi mulai ditingkatkan kepada seluruh lapisan masyarakat karena merupakan hak setiap orang untuk belajar sepanjang hayat. Dengan meningkatkan kemampuan literasi, masing-masing individu diharapkan dapat memberdayakan dan meningkatkan kualitas hidup baik itu secara individu, keluarga, maupun dalam masyarakat.

Kebiasaan membaca masyarakat masih sangat minim. Hal ini ditandai dengan adanya sebagian masyarakat yang melakukan kegiatan membaca buku jika sedang membutuhkan sumber bacaan untuk mengerjakan tugas. Fenomena seperti ini juga sering terjadi saat seorang mahasiswa sedang menyusun tugas akhir atau skripsi. Maka dari itu kebiasaan membaca harus selalu dibiasakan mulai sejak dini. Keterampilan membaca dapat meningkatkan 
kemampuan seseorang untuk memahami berbagai konsep dengan mudah. Hal ini juga dapat meningkatkan keterampilan berpikir kritis pada anak-anak.

Anak usia dini disebut sebagai usia kritis atau usia sensitif. Pada masa ini potensi anak banyak berkembang. Namun jika potensi itu tidak distimulasi dengan baik, justru akan menimbulkan masalah yang cukup fatal dalam kehidupan anak selanjutnya. Pendidikan anak usia dini sangat penting dilaksanakan sebagai dasar bagi pembentukan kepribadian manusia seutuhnya, yaitu pembentukan karakter, budi pekerti yang baik, cedas, ceria dan bertakwa kepada Allah. Menurut pakar pendidikan, Aliyah Rasyid, anak-anak yang pada masa prasekolah sudah dikondisikan untuk mengeluarkan daya kreatifitasnya, seperti menggambar, permainan, edukatif dan kebebasan bertindak akan memiliki perkembangan kecerdasan yang lebih (Noorlaila, 2010:6).

Guru maupun orang tua perlu mengetahui kemampuan awal literasi anak sehingga dapat mendiagnosis kesulitan anak terkait kemampuan literasinya serta membantu anak dalam mengembangkan kemampuan literasinya (Schikedanz, 2013:63). Pengalaman anak berinteraksi dengan literasi sejak dini akan menyiapkan anak secara matang untuk mengikuti pembelajaran di sekolah formal. Laporan penelitian PISA (2003) memberikan gambaran bahwa kemampuan membaca yang baik akan meningkatkan konsep diri anak, yang pada akhirnya akan memotivasi mereka untuk belajar. Selanjutnya, ditemukan kebiasaan membaca yang baik dan ada kontinuitas keterlibatan dengan aktivitas membaca akan menentukan keberhasilan anak mendapatkan pengetahuan.

Salah satu upaya pemerintah dalam rangka meningkatkan pendidikan berkualitas adalah melalui meningkatkan budaya literasi (membaca dan menulis). Untuk menyukseskan rencana besar ini tidak bisa instan, maka dibutuhkan suatu pembiasaan yang harus terus menerus dilakukan sejak usia dini. Program ini bukan untuk diterapkan kepada siswa saja tetapi semua warga sekolah juga harus terlibat.

Saat ini banyak kegiatan pembiasaan untuk memulai gerakan literasi sekolah. Hal yang utama adalah kemauan dari seluruh warga sekolah untuk menyukseskan program tersebut, di antaranya mendekatkan buku sedekat mungkin dengan anak-anak. Kemudahan dalam mengakses buku telah dicontohkan oleh Cakruk Baca Bergerak yang mempunyai visi 
sebagai pusat rujukan peningkatan ilmu pengetahuan, informasi, dan ekonomi bagi masyarakat sekitar.

Cakruk Baca Bergerak dipelopori oleh Eko Sanyoto Nugroho yang beralamat di Dusun Demangan, RT 10 RW 04, Desa Kadirejo, Kecamatan Pabelan, Kabupaten Semarang Jawa Tengah. Cakruk Baca Bergerak adalah upaya membangun budaya baca dan literasi, khususnya kepada generasi penerus bangsa. Tujuannya tidak lain agar generasi bangsa menjadi cerdas, dapat memiliki wawasan yang luas, mampu bersikap analitis, kritis dan logis. Cakruk Baca Bergerak berkeliling memberi layanan membaca gratis ke sekolah dan kampung di wilayah Desa Kadirejo, Kecamatan Pabelan dan sekitarnya.

Cakruk Baca Bergerak lahir dari wujud keprihatinan terhadap masyarakat Desa Kadirejo yang berbeda dengan masyarakat kota. Diketahui bahwa warga kota bisa memanfaatkan fasilitas yang ada di perpustakaan mulai dari peminjaman koleksi buku, penggunaan komputer dan internet, ruang anak dan lainnya secara gratis, sedangkan di desa sama sekali tidak ada fasilitas seperti itu. Menyadari kenyataan yang demikian, maka muncullah Cakruk Baca Bergerak yang secara sukarela mengamalkan ilmu yang dimiliki dan mengembangkan budaya baca dan literasi di daerah sekitarnya dengan berusaha memberi kemudahan bagi anak-anak dan masyarakat dalam memperoleh bahan bacaan dengan cara berkeliling memberi layanan membaca gratis.

Tradisi membaca dan menulis harus terus dikembangkan karena melalui membaca, kemajuan pendidikan akan lebih pesat. Melalui kegiatan menulis, ide, gagasan, dan ilmu pengetahuan akan terus berkembang. Melalui tulisan, ide dan gagasan akan lebih dikenang sepanjang masa dibandingkan hanya terucapkan secara lisan. Orang masih menganggap sepele akan pentingnya membaca. Membaca masih sebatas kebutuhan ketika kita diperlukan saja. Paradigma inilah yang harus diubah untuk menjadikan membaca sebagai kewajiban. Minimnya minat baca masyarakat disebabkan pula belum ada kebiasaan membaca yang ditanamkan sejak usia dini.

Berdasarkan uraian di atas, permasalahan di dalam tulisan ini dapat dirumuskan ke dalam deskripsi tentang bagaimana peran Cakruk Baca Bergerak dalam pengembangan literasi anak usia dini di RA Miftahul Falah Kadirejo sekaligus faktor-faktor yang mendukung dan menghambat upaya pengembangan itu. 
Penelitian tentang literasi anak usia dini sesungguhnya telah beberapa kali dilakukan. Gustini dan Mulyana (2016), misalnya, menemukan bahwa perpustakaan Elmuloka menyelenggarakan program secara kreatif dalam membangun budaya literasi pada anak-anak. Di samping melibatkan guru dan orang tua, Elmuloka juga bekerja sama dengan komunitas pecinta buku dalam menjalankan programnya. Elmuloka juga menggandeng storyteller volunteer dari dalam dan luar negeri. Basyiroh (2017) pernah melakukan kajian tentang program pengembangan literasi di TK Negeri Centeh. Hasilnya yaitu pengembangan literasi anak di TK tersebut dilakukan melalui aktivitas seperti bermain kartu, arisan, main sedotan, main kubus, kotak rahasia, berburu kata, dan menempel huruf. Hapsari, Ruhaena, dan Pratisti (2017) mendapatkan temuan bahwa terdapat perbedaan peningkatan kemampuan literasi awal pada kelompok eksperimen (yang diberi program stimulasi) dengan kelompok kontrol (tanpa program stimulasi).

\section{METODOLOGI}

Penelitian kualitatif ini menggambarkan secara sistematis mengenai fakta-fakta yang ditemukan di lapangan. Penelitian dilaksanakan di RA Miftahul Falah Kadirejo Pabelan Kabupaten Semarang pada Februari 2018. Teknik pengumpulan data yang digunakan adalah observasi, wawancara, dan dokumentasi. Teknik pertama berupa observasi langsung, yaitu secara partisipatif ada keterlibatan peneliti dalam kegiatan sehari-hari orang yang diamati atau yang digunakan sebagai sumber data penelitian. Teknik kedua berbentuk kontak langsung secara lisan atau tatap muka dengan sumber data. Sumber data primer dari kajian ini adalah Eko Sanyoto Nugroho, pelopor Cakruk Baca Bergerak. Data penelitian juga diperoleh dari Kepala dan guru RA Miftahul Falah. Teknik dokumentasi terdukung dengan adanya dokumen berupa foto kegiatan.

Teknik analisis data penelitian ini berupa analisis deskriptif, meliputi pengumpulan data, reduksi data, penyajian data, dan penarikan kesimpulan. Teknik tersebut mengacu pada model analisis interaktif Miles \& Huberman (1992: 20), seperti skema berikut: 


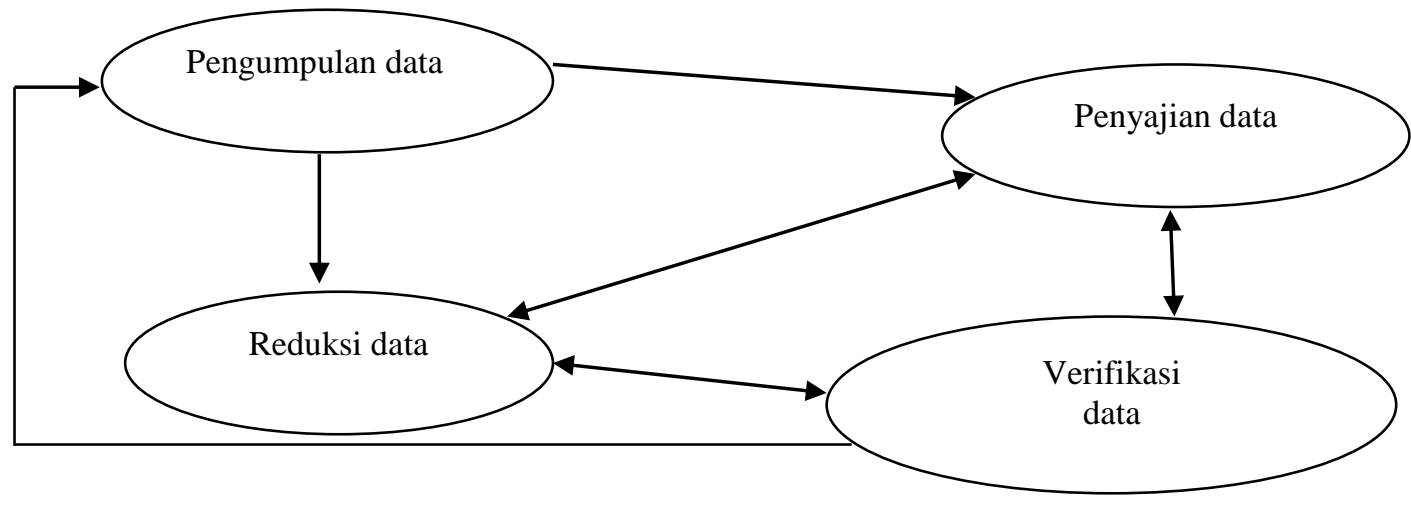

\section{Gambar 1. Teknik Analisis Data}

Triangulasi sumber dimanfaatkan untuk menguji keabsahan data. Teknik itu dilakukan dengan membandingkan dan mengecek derajat kepercayaan suatu informasi yang diperoleh melalui waktu dan alat yang berbeda. Praktisnya, teknik ini dilaksanakan dengan membandingkan data yang satu dengan sumber data yang lain, seperti perbandingan data pengamatan dengan hasil wawancara atau dokumentasi.

\section{HASIL DAN PEMBAHASAN}

Istilah literasi dalam bahasa Indonesia merupakan kata serapan dari bahasa Inggris literacy yang secara etimologi berasal dari bahasa Latin literatus yang artinya ditandai dengan huruf, melek huruf, atau berpendidikan (Toharudin, 2011: 1). Pengertian literasi berdasarkan konteks penggunaanya dinyatakan oleh Baynham bahwa literasi merupakan integrasi keterampilan menyimak, berbicara, menulis, membaca, dan berpikir kritis (Baynham, 1995:9).

Literasi dalam pemahaman lama disamakan dengan istilah melek huruf dan keaksaraan. Literasi telah mengalami perluasan makna sedemikian rupa sebagai sebuah kemampuan dasar manusia untuk memahami, menganalisis dan mengolah informasi dalam dan untuk kehidupan. Menghargai dan mencintai buku adalah salah satu ciri masyarakat dengan literasi yang baik. Hal ini senada dengan ungkapan Ngainun Naim, sebagaimana dikutip oleh Suragangga (2017:156), bahwa untuk menciptakan kemajuan peradaban suatu daerah salah satunya dengan menumbuhkembangkan tradisi literasi.

Literasi anak usia dini adalah kemampuan yang dimiliki oleh anak yang berkaitan dengan membaca dan menulis. Pengenalan literasi anak usia dini adalah suatu aktivitas 
memperkenalkan kemampuan membaca dan menulis pada anak usia dini tanpa adanya paksaan dan sesuai dengan usia atau fase-fase perkembangannya. Pengenalan literasi awal pada anak usia dini yang dilakukan dengan cara yang menyenangkan akan menjadikan anak tidak bosan sehingga menjadi bekal bagi anak dalam mencintai budaya membaca dan menulis yang akan membantu anak mengomunikasikan ide dan perasaannya kepada orang lain.

McGee dan Purcell-Gates menyebutkan bahwa perkembangan literasi berisi dua periode waktu, secara rinci dimulai dari lahir sampai usia lima tahun dan dari usia lima tahun sampai dengan menjadi pembaca yang mandiri (Abidin, 2015:29). Kemampuan literasi atau kemampuan berkomunikasi pada anak akan mempengaruhi perkembangan sosial, emosi, dan perkembangan kognitifnya (Harlock, 1978:178). Kemampuan berkomunikasi secara lisan atau tulisan seperti kemampuan membaca dan menulis merupakan kemampuan dasar yang harus dimiliki setiap orang.

Suyadi (2010:102) mengemukakan bahwa kemampuan literasi dapat diperkenalkan atau diajarkan kepada anak usia dini sejak anak berada dalam kandungan. Stimulasi perkembangan literasi pada anak usia dini dapat diuraikan sebagai berikut:

1. Bayi (Infants)

Sejak dalam kandungan idealnya anak distimulasi atau diperkenalkan berbagai aktivitas yang membuat kemampuan literasinya berkembang. Pengenalan literasi bisa dilakukan pada saat anak berbaring, tengkurap, atau duduk. Bahkan, di atas tempat tidur anak perlu disediakan buku-buku berwarna (full colour) atau orang tua yang membacakan cerita. Pengenalan literasi pada periode ini hanya sebatas memperkenalkan, bukan memaksa anak untuk menghafal.

\section{Toddlers (2-3 tahun)}

Pada dasarnya toldders sangat menggemari buku. Jika stimulasi pada masa ini berhasil, anak-anak akan mempunyai kecenderungan untuk menyukai buku. Umumnya pada masa ini anak-anak mulai membaca dan gemar memberikan nama pada objek-objek yang ada di dalam buku tersebut. Seiring berjalannya waktu dan bertambahnya kosa kata atau tanda yang dikenali, anak dapat dikenalkan untuk membaca tetapi bukan untuk menghafal. Pembacaan buku secara nyaring dan dengan intonasi yang tepat merupakan langkah yang paling strategis menstimulasi pendengaran anak. 
3. Anak usia $3-6$ tahun

Pada masa ini kesenangan anak terhadap buku cerita mulai meningkat tajam. Anak menyukai buku-buku cerita yang masih banyak ilustrasi gambar-gambar dan warna-warna cerah. Sebab, seperti disitir dari Kaderavek (2002), pada hakikatnya periode literasi anak dimulai dari lahir sampai dengan usia enam tahun. Dengan demikian pemberian literasi yang paling baik bagi anak pada tahap ini adalah membacakan cerita, kisah, dan membacakan dongeng. Cara lain adalah meminta anak menceritakan ulang cerita tersebut walaupun tidak selengkap cerita aslinya.

Selanjutnya dikemukakan bahwa membaca buku bermutu selain memperluas pengetahuan seseorang juga mampu mengembangkan daya pikir dan mengembangkan kreativitas serta mengenal dan memahami diri sendiri dan orang lain. Dengan demikian melalui membaca dapat mengembangkan pribadinya. Selain itu dengan membaca bacaan bermutu akan meningkatkan berfungsinya otak. Secara generik otak telah terbentuk sejak lahir, tetapi interaksi dengan lingkungan sangat menentukan bagaimana otak manusia berfungsi (Semiawan, 2002: 27).

Kesiapan anak belajar membaca dan menulis tergantung dari IQ anak, tetapi tidak semata-mata IQ saja. Berikut ini beberapa faktor yang mempengaruhi kesiapan membaca anak:

\section{Kesiapan fisik}

Anak yang sehat akan cepat belajar membaca dan menguasai pelajaran daripada anak yang sakit. Anak yang sakit tidak bergairah dalam belajar, sehingga guru harus yakin bahwa anak memiliki indra yang sehat, seperti penglihatan yang sehat, pendengaran yang sehat, dan alat bicara yang sehat.

\section{Kesiapan psikologis}

Sebelum aktivitas belajar membaca, terlebih dahulu guru mengetahui kondisi psikologi setiap anak. Kemudian anak diberi motivasi untuk melupakan persoalan-persoalan yang ada sehingga ia merasa tenang, nyaman, dan dapat beradaptasi dengan lingkungan belajarnya.

3. Kesiapan pendidikan 
Kesiapan membaca sangat tergantung pada pengalaman anak tentang apa yang dilihat, dirasa, didengar, dan dirasakan olehnya. Kosa kata anak juga harus memadai. Banyaknya kosa kata yang dikuasai anak akan membantu anak dalam belajar membaca. Banyaknya perolehan kosa kata tergantung pada pengalamannya di lingkungan sekitar. Membaca juga tergantung pada kejelasan anak dalam berbicara. Kemampuan anak dalam mengucapkan kata-kata dengan jelas dan tepat dapat dijadikan dasar bahwa ia siap belajar membaca (Musthafa, 2005:31).

Beberapa penelitian menunjukan bahwa anak yang sejak dini akrab dengan dunia buku kelak di masa dewasa ia akan mempunyai minat baca yang tinggi (Gustini, 2016:342). Adapun cara untuk meningkatkan kegemaran membaca dapat dilakukan dengan beberapa cara berikut:

1. Memberi tes kalimat tidak sempura. Anak-anak diminta mengisi kata-kata yang seharusnya ada di dalam kalimat, sehingga menjadi kalimat yang sempurna.

2. Deteksi kesalahan, artinya ada beberapa kalimat yang sengaja dibuat salah berkenaan dengan isi bacaan, kemudian dibetulkan oleh anak.

3. Menceritakan kembali isi bacaan dengan bahasa anak sendiri.

4. Memberi kebebasan anak untuk bertanya tentang suatu bacaan.

5. Memeragakan bacaan (Semiawan, 2012:29).

Cakruk Baca Bergerak merupakan tempat baca berupa gazebo sederhana yang dipelopori oleh Eko Sanyoto Nugroho. Cakruk tersebut resmi berdiri pada 29 Juli 2017 dengan disaksikan Ketua RT, Ketua RW, Kepala Dusun, dan tokoh masyarakat sekitar Desa Kadirejo. Cakruk Baca tidak hanya dijadikan homebase untuk memudahkan identitas, tetapi tidak sedikit pula anak-anak yang datang untuk meminjam buku maupun sekedar membaca. Sementara itu, kegiatan intinya adalah melakukan kegiatan keliling membaca gratis dengan mengoperasikan motor perpustakaan keliling ke lembaga-lembaga pendidikan yang belum mempunyai perpustakaan, salah satunya adalah RA Miftahul Falah Kadirejo yang berjarak kurang lebih $1 \mathrm{Km}$ dari Cakruk Baca.

Visi dari Cakruk Baca Bergerak adalah menjadikan generasi penerus bangsa yang cerdas, dapat memiliki wawasan yang luas, mampu bersikap analitis, kritis dan logis, serta menjadikan Cakruk Baca Bergerak sebagai pusat rujukan peningkatan ilmu pengetahuan, 
informasi, dan ekonomi bagi masyarakat sekitar. Sedangkan misinya adalah (1) menyediakan bahan bacaan bagi masyarakat sesuai dengan kebutuhan dan perkembangan ilmu pengetahuan dan informasi; dan (2) menyediakan fasilitas lain yang mendukung pengembangan budaya baca dan literasi, peningkatan intelektual dan ekonomi masyarakat.

Layanan yang dilakukan oleh Cakruk Baca Bergerak antara lain yakni layanan keliling membaca gratis ke TK/RA, SD/MI dan kampung-kampung di Kecamatan Pabelan dan sekitarnya setiap Selasa, Rabu, Kamis, Jum'at dan Sabtu. Cakruk Baca Bergerak dengan suka rela berkeliling ke kampung-kampung dengan bermodalkan sepeda motor sambil membawa buku-buku yang disukai anak-anak.

Kedatangan Cakruk Baca ternyata senantiasa disambut dengan senang dan suka cita oleh anak-anak. Tidak heran, menurut kepala RA Miftahul Falah, anak-anak seringkali berebut buku untuk mendapatkan buku yang diinginkan. Dengan gaya masing-masing yang unik, anak-anak menikmati buku sambil bermain di ayunan, di pelosotan, di terowongan, sembari membolak balik buku selembar demi selembar untuk melihat gambarnya, mewarnai buku, bertanya kepada teman, guru, dan pemilik Cakruk Baca tentang buku yang dilihatnya. Selain itu anak-anak juga meminta untuk diceritakan tentang buku yang dipegangnya. Kebiasaan tersebut berefek positif kepada anak-anak, bahwa mereka menjadi percaya diri untuk menceritakan buku yang dipegang kepada temannya, berani mengeskpresikan diri dari buku yang dilihatnya untuk menirukan gayanya dan lain-lain. Keberadaan Cakruk Baca Bergerak sangat membantu RA Miftahul Falah dalam mengembangkan literasi anak yang jarang sekali didapatkan ketika di rumah, baik karena kesibukan orang tua maupun karena tidak ada sarana untuk dibaca oleh mereka. 


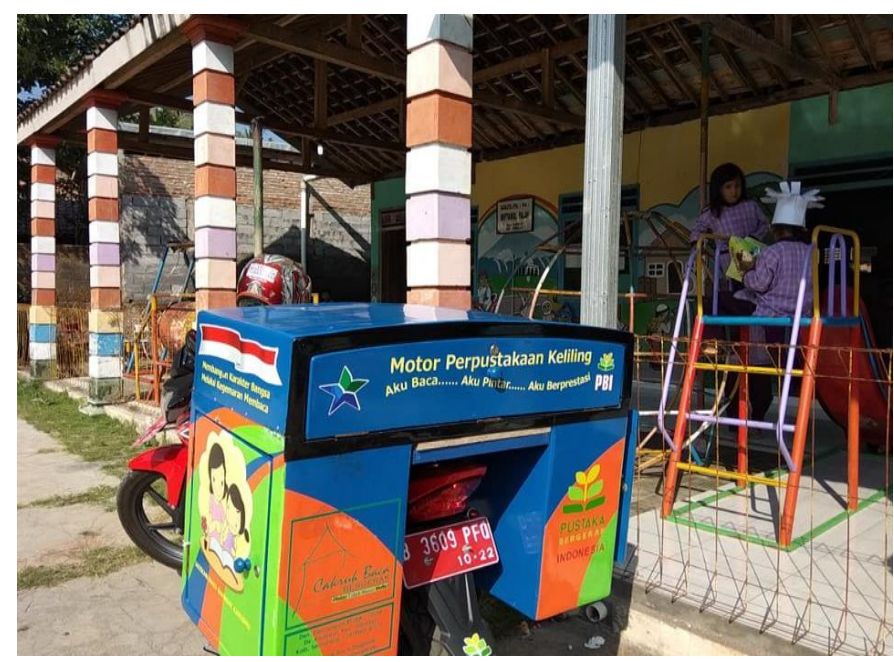

\section{Gambar 2 Kunjungan Cakruk Baca Bergerak ke RA Miftahul Falah}

Kegiatan lain yang dilakukan Cakruk Baca Bergerak selain memberikan pelayanan membaca kepada anak-anak juga memberikan kegiatan yang menyenangkan kepada anak. Aktivitas itu di antaranya adalah lomba mewarnai, kegiatan gerakan membaca anak dengan orang tua di sekolah, bermain peran menjadi pustakawan dan pengunjung, kunjungan ke perpustakaan Salatiga, lomba bercerita, membacakan dongeng, menonton film bersama, dan lain-lain. Kegiatan literasi tidak hanya sebatas anak diberi buku dan diminta untuk membacanya, akan tetapi dapat melalui penyediaan permainan-permainan yang menyenangkan.

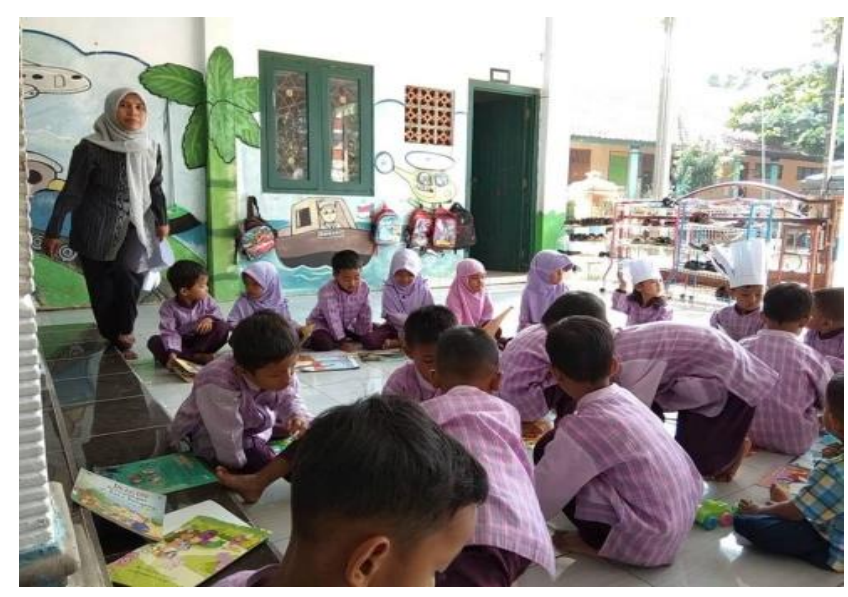

\section{Gambar 3. Kegiatan Literasi RA Miftahul Falah}

Jenis permainan yang mendukung program peningkatan kemampuan literasi pada anak di antaranya adalah bermain peran, bermain kubus, bermain arisan, bermain kartu kata, 
bermain koin dan gambar, bermain kotak rahasia, dan bermain sedotan. Jenis-jenis permainan ini bertujuan mengenalkan huruf atau simbol yang dilakukan dengan berulang ulang. Jika hal ini dilakukan terus menerus anak mampu membaca dan menulis secara alami tanpa paksaaan (Basyiroh, 2017:120). Tujuan utama dari kegiatan tersebut adalah untuk menumbuhkan minat anak untuk membaca dan menanamkan anak untuk mencintai buku. Kegiatan yang bervariasi dilakukan agar anak tidak bosan dan penanaman karakter cinta literasi dapat berkembang dengan baik. Hal senada diungkapkan oleh Ruhaena (2015:47), bahwa anak memiliki kebutuhan untuk mendapat stimulasi literasi yang menarik perhatian dan menggugah minat mereka terhadap kegiatan literasi. Oleh karena itu dikembangkan model stimulasi yang bersifat multisensoris (audio, visual, dan kinestetik) agar perhatian dan minat anak meningkat.

Suyadi (2010:96) mengemukakan bahwa anak belajar literasi atau bahasa secara alamiah. Anak-anak memperoleh pengetahuan tentang membaca dan menulis tidak melalui pengajaran, tetapi melalui perilaku yang sederhana dengan mengamati dan berpartisipasi pada aktivitas yang berkaitan dengan literasi. Anak akan memperoleh kemampuan untuk mengembangkan literasinya dengan mengamati orang yang melakukan aktivitas literasi dan berpartisipasi dengan aktivitas tersebut maka. Ditambahkan, untuk meningkatkan literasi anak, suasana di sekolah dan di rumah juga harus menunjang kebiasaan membaca anak. Jangan sampai orang tua atau guru tidak gemar membaca tetapi menuntut anaknya memiliki kegemaran membaca. Selain itu dengan menyediakan bacaan-bacaan yang mengasyikkan akan menjadikan anak betah untuk membaca sehingga keingintahuan anak tetang ilmu pengetahuan juga bertambah (Semiawan, 2008:31).

Kedatangan Cakruk Baca Bergerak membantu kesulitan RA Miftah Falah dalam mencukupi kebutuhan anak-anak demi perkembangan literasinya. Diketahui bahwa RA Miftahul Falah memiliki sudut baca yang berisi beberapa buku cerita anak dan majalahmajalah anak dengan jumlah yang sangat terbatas. Anak-anak pun harus bergantian dan menunggu giliran ketika ingin membaca buku. Anak-anak juga sudah merasa bosan dengan koleksi buku yang pernah dilihatnya, sehingga sudut baca menjadi sudut yang jarang sekali dikunjungi anak-anak. Beberapa koleksi buku di sudut baca hanya sebagai pengisi rak buku saja tanpa sentuhan dari anak-anak.

Menurut Kepala RA Miftahul Falah, Cakruk Baca Bergerak memberi inspirasi kepada 
lembaga RA Miftahul Falah Kadirejo untuk membantu pengembangan literasi anak dengan mengembangkan Sudut Baca menjadi Perpustakaan Mini RA Miftahul Falah. Tujuan perpustakaan mini adalah supaya anak dapat berbaur dengan buku bacaan tidak hanya ketika Cakruk Baca Bergerak datang saja, tetapi anak dapat belajar membaca, bercerita, menulis setiap hari tanpa batas. Dengan beberapa koleksi buku yang dimiliki RA Miftahul Falah dan sumbangan buku dari Cakruk baca Bergerak, Perpustakaan Mini RA Mifahul Falah dapat terwujud dan dapat dimanfaatkan anak-anak setiap harinya. Koleksi buku bacaan yang dimiliki RA Miftahul Falah semakin bertambah banyak dan bervariasi sehingga membantu meningkatkan minat anak untuk lebih dekat dengan buku, lebih mencintai buku dan budaya membaca lebih berkembang.

Upaya pengembangan literasi anak usia dini ternyata tidak semudah membalikkan telapak tangan. Itu pula yang dialami oleh Cakruk Baca bergerak dan RA Miftahul Falah. Dalam pengembangan literasi tidak terlepas dari beberapa hal yang dapat menghambat pelaksanaan penerapannya. Namun tidak dipungkiri ada faktor pendukung yang dapat membangkitkan semangat pengembangan literasi pada anak usia dini di RA Miftahul Falah.

Berdasarkan observasi dan wawancara, pelaksanaan pengembangan literasi anak usia dini melalui Cakruk Baca di RA Miftahul Falah memiliki beberapa hambatan, seperti:

1. Terbatasnya waktu pelaksanaan kunjungan di RA Miftahul Falah. Kunjungan dilaksanakan hanya dua minggu sekali dengan durasi 30 menit saja, yaitu ketika anak-anak istirahat, sehingga ketika anak sedang asyik bermain dengan buku, anak harus masuk untuk melaksanakan pembelajaran berikutnya.

2. Kurangnya dukungan membaca dan menulis di rumah karena minimnya fasilitas membaca dan menulis sebagai tindak lanjut pengembangan literasi. Sepertinya buku bukan hal primer yang harus disediakan di rumah. Ketika Cakruk Baca Bergerak datang tidak semua anak mau bermain dengan buku karena kebiasaan di rumah yang masih melekat pada anak.

3. Kurangnya budaya membaca di rumah, karena orang tua sibuk bekerja dan minat baca orang tua juga rendah sehingga anak mengikuti kebiasaan yang ada dalam keluarga.

Hal yang sama diungkapkan oleh Idris dan Ramdani (2015:3), bahwa berbagai macam kendala yang harus diperangi untuk menciptakan gerakan Indonesia membaca yaitu:

1. Kurangnya tersediannya bacaan yang menarik. 
2. Minimnya perhatian pemerintah terhadap pendidikan formal maupun nonformal.

3. Kebiasaan malas membaca yang telah mengakar di masyarakat.

4. Daya beli buku yang minim karena tingkat ekonomi yang kurang merata di kalangan masyarakat Indonesia.

5. Kurang tersebarnya sarana membaca (perpustakaan dan taman baca).

6. Sistem pendidikan yang kurang memaksimalkan perpustakaan.

Kendala keempat di atas dikuatkan dengan kajian yang pernah dilakukan oleh Adedokun (2013: 466). Penelitian yang melibatkan 100 responden itu menghasilkan temuan bahwa anak-anak dari keluarga kurang mampu ternyata mengalami kesempatan untuk mengembangkan literasi yang tidak sebesar anak-anak yang berasal dari keluarga berada. Namun demikian, adanya faktor penghambat dalam pengembangan literasi anak usia dini oleh pengelola Cakruk Baca Bergerak dianggap bukan sebagai suatu halangan, akan tetapi justru dijadikan sebagai tantangan dalam mewujudkan pendidikan yang lebih baik. Untuk mengatasi hal tersebut pengelola selalu saling tukar pendapat, pengalaman, dan bekerja sama dengan pegiat literasi yang lain dalam menghadapi tantangan, sehingga kemampuan literasi anak berkembang sangat baik dan dapat membekali anak menghadapi kemajuan zaman.

Pengenalan literasi merupakan salah satu tugas yang harus dikembangkan dan dikenalkan untuk anak usia dini. Beberapa faktor pendukung Cakruk Baca Bergerak dalam pengembangan literasi di RA Miftahul Falah adalah:

1. Koleksi buku Cakruk Baca Bergerak yang sudah mencapai kurang lebih 2.000 buku. Koleksi buku untuk anak usia dini sendiri sekitar 300 buku.

2. Dukungan pemerintah yang memberikan hibah buku kepada Cakruk Baca Bergerak sehingga menjadi koleksi tambahan untuk dibaca anak-anak.

3. Dukungan sekolah yang memberikan tempat dan waktunya sehingga anak dapat meluangkan waktu untuk membaca bersama, bercerita bersama yang dapat meningkatkan literasinya.

4. Keterampilan guru dalam mengelola kegiatan literasi sehingga anak tidak bosan. Guru mendukung dengan memberi kesempatan anak untuk berekspersi dan bereksperimen dari 
informasi yang didapatkan setelah membaca buku, sehingga anak lebih kreatif dan imaginatif.

5. Dukungan orang tua yang meluangkan waktu ke sekolah untuk mendampingi anak dalam kegiatan membaca bersama. Hal itu sebagai bentuk kepedulian dan perhatian kepada anak sehingga kepercayaan diri anak berkembang.

6. Dukungan dan kerjasama antara Cakruk Baca Bergerak dengan pegiat literasi yang berada di seluruh wilayah Indonesia sehingga membantu kesulitan-kesulitan yang dihadapi.

Peran dari semua pihak serta berbagai kegiatan yang bervariasi yang menyenangkan akan sangat membantu dalam menstimulasi perkembangan literasi. Kebiasaan orangtua/keluarga merupakan suatu bentuk keterlibatan yang dapat mempengaruhi minat literasi anak. Keluarga yang memiliki kebiasaan literasi dan membiarkan anak terlibat di dalamnya membuka peluang yang lebih besar untuk menumbuhkan minat literasi. Bagi anak yang belum bisa membaca, orang tua atau guru bisa menggunakan metode bercerita dengan memperlihatkan buku yang berisi gambar-gambar agar anak mengenal buku dan tertarik untuk membacanya. Buku-buku perlu disusun di tempat yang mudah dijangkau anak agar anak bisa bermain dengan buku dan menganggap buku sebagai sesuatu yang baru. Keberhasilan sebuah tujuan adalah adanya keselarasan antara keluarga, sekolah, dan masyarakat sehingga mampu mencetak generasi yang cerdas, kreatif, dan berkarakter. Semua keterampilan itu bisa diwujudkan, salah satunya melalui kegiatan membaca.

Penyediaan fasilitas yang lengkap dan bervariasi akan membantu anak dalam pembelajaran literasi yang lebih cepat. Hal ini dikarenakan anak tidak merasa jenuh dengan fasilitas yang monoton dan dapat mengembangkan kreativitasnya dengan menggunakan bentuk fasilitas lain. Fasilitas yang lengkap juga akan menstimulasi anak untuk beraktivitas literasi dan menanamkan minat literasi. Ditengarai di sini bahwa fasilitas yang lengkap akan selalu memacu anak untuk selalu ingin tahu. Adapun bentuk fasilitas yang dapat menstimulasi minat anak adalah yang menarik bagi anak dan dapat digunakan sembari anakanak bermain.

\section{SIMPULAN}

Cakruk Baca Bergerak banyak memberikan kontribusi positif kepada anak-anak di RA 
Miftahul Falah. Anak-anak menjadi lebih bebas mengeskpresikan dirinya dengan belajar membaca, menulis, mewarnai, bercerita, bertanya, dan lain-lain. Anak mulai dekat dengan buku, bermain dengan buku, meski hanya sekadar membolak-balik untuk melihat gambar dan menceritakannya kepada teman yang lain.

Cakruk Baca Bergerak tidak hanya memberikan pelayanan membaca buku saja, akan tetapi dengan mengadakan variasi kegiatan seperti lomba mewarnai, lomba bercerita, bermain peran dan lain-lain. Variasi kegiatan yang dihadirkan oleh Cakruk Baca Bergerak dan RA Miftahul Falah dapat mengatasi kebosanan anak sehingga tujuan dari pengembangan literasi dapat berkembang baik.

Pengembangan literasi melalui Cakruk Baca Bergerak di RA Miftahul Falah didukung dengan (1) cukup banyaknya koleksi buku untuk anak, (2) hibah buku dari pemerintah kepada pengelola Cakruk Baca, (3) penyediaan waktu dan tempat oleh sekolah, (4) pendampingan guru dan orang tua kepada anak selama di sekolah, dan (5) kerja sama pengelola Cakruk Baca dengan pegiat literasi. Di sisi lain, upaya tersebut menemui hambatan berupa (1) keterbatasan waktu kunjungan, (2) minimnya sarana dan prasarana untuk membaca di rumah, dan (3) kurangnya budaya membaca di rumah.

\section{DAFTAR PUSTAKA}

Adedokun, M.O. (2013). Literacy in Early Childhood: Implications for Sustainable Development. Annual International Interdisciplinary Conference, (hal. 466-472). Azores, Portugal.

Basyiroh, I. (2017). Program Pengembangan Kemampuan Literasi Anak Usia Dini (Studi Kasus Best Practice Pembelajaran Literasi Di TK Negeri Centeh Kota Bandung). Tunas Siliwangi, Volume 3, Nomor 2, Oktober 2017.

Baynham, M. (1995). Literacy Practices: Investigating Literacy in Social Contexts. London: Longman.

Gustini, L. K. dan Mulyana, S. (2016), Membangun Budaya Literasi Pada Anak Usia Dini Serta Anak Usia Pendidikan Dasar Melalui Aktivitas Kreatif Perpustakaan Elmuloka Bandung, Prosiding Seminar Nasional Komunikasi 2016. Bandung: Politeknik LP3I Bandung Fikom Unpad.

Hapsari, W., Ruhaena, L. dan Pratisti W.D. (2017). Peningkatan Kemampuan Literasi Awal Anak Prasekolah melalui Program Stimulasi. Jurnal Psikologi, Volume 44, Nomor $3,177-184$.

Hurlock, E. B. (1978). Child Development, terj. Meitasari Tjandrasa. Jakarta: Erlangga. 
Idris, M. H. dan Ramdani, I. (2015). Menumbuhkan Minat Membaca Pada Anak Usia Dini. Jakarta: Luxima Metro Media.

Miles, M. B. dan Huberman, A.M. (1992). Analisis Data Kualitatif, terj. Tjetjep Roehendi Rohidi. Jakarta: UI Press.

Musthafa, F. (2005). Agar Anak Anda Gemar Membaca. Bandung: Hikmah.

Nawawi, H. H. (2012). Metode Penelitian Bidang Sosial. Yogyakarta: Gadjah Mada University Press.

Noorlaila, I. (2010). Panduan Lengkap PAUD. Yogyakarta: Pinus Book Publisher.

PISA. (2003). New York: Literacy skills for the world of tomorrow. OECD/UNESCOIS.www.uis.unesco.org/TEMPLATE/pdf/pisa/PISAplus Eng Ch4.

Ruhaena, L. (2015). Model Multisensori: Solusi Stimulasi Literasi Anak Prasekolah. Jurnal Psikologi. Volume 42, Nomor 1, April 2015: 47 - 60.

Schikedanz, J. A. (2013). Spesial Issue: Early Literacy. Asia-Pasific Journal of Research in Early Childhood Education. Volume 7, Nomor 2.

Semiawan, C. R. (2002). Belajar dan Pembelajaran Prasekolah dan Sekolah Dasar. Jakarta: Indeks.

Suragangga, I. M. N. (2017). Mendidik Lewat Literasi Untuk Pendidikan Berkualitas. Jurnal Penjaminan Mutu Institut Hindu Dharma Negeri Denpasar. Volume 3 Nomor 2. Denpasar: IHDN Denpasar.

Suyadi. (2010). Psikologi Belajar PAUD. Jogjakarta: Pedagogia.

Toharudin, dkk. (2011). Membangun Literasi Sains Peserta Didik. Bandung: Humaniora. 